\title{
Sistem Pendukung Keputusan untuk Pemilihan Program Studi menggunakan Metode VARK dan Backward Chaining
}

\author{
Rio Azhari Ramadhan1, Safitri Jaya ${ }^{2}$, M. Nasucha ${ }^{3}$ \\ 1,2,3Universitas Pembangunan Jaya, Jl Cendrawasih Raya Blok B7/P, Sawah Baru, Kec. \\ Ciputat, Kota Tangerang Selatan, Banten, 15413 \\ 1rio.azhari@student.upj.ac.id , ${ }^{2}$ safitri.jaya@.upj.ac.id, ${ }^{3}$ mohammad.nasucha@upj.ac.id
}

Article History:

Received

2021-10-05

Review

2021-12-17

Revised

2021-12-27

Accepted

2021-12-28

Published

2021-12-28
Abstract. Abstract. Choosing a study program is the initial decision taken by prospective students when deciding to continue their studies at the tertiary level. Before choosing, prospective students are expected to understand well what their interests and talents are. Errors in making choices certainly have an impact on the continuity of the study period. Lack of interest or talent in the chosen study program will give results that are not optimal. Not infrequently we encounter many students who decide to change study programs or even drop out of study just because of this. Problems and errors like this are quite common among students. Therefore, in this study, an approach to learning style (VARK) is tried as a basis for drawing conclusions that approach the interests and talents of prospective students in determining the choice of the appropriate study program. The conclusions obtained will be traced back by looking for a set of hypotheses to the facts that support the hypothesis (Backward Chaining). Based on the computational tests conducted using the two methods, the results show that the analytical approach can be used in providing recommendations for the choice of study programs that are in accordance with the abilities of prospective students.

Keywords: choice of study program, learning style, recommendations

Abstrak. Memilih program studi adalah keputusan awal yang diambil oleh calon mahasiswa ketika memutuskan untuk melanjutkan studi di jenjang perguruan tinggi. Sebelum memilih, calon mahasiswa diharapkan dapat memahami dengan baik apa yang menjadi minat serta bakat yang dimiliki. Kesalahan dalam menentukan pilihan tentunya berdampak pada keberlangsungan masa studi. Kurangnya minat atau bakat pada program studi yang dipilih akan memberikan hasil yang tidak maksimal. Tidak jarang kita jumpai banyak mahasiswa yang memutuskan untuk pindah program studi atau bahkan putus studi hanya disebabkan oleh hal tersebut. Permasalahan dan kesalahan seperti ini cukup sering terjadi di kalangan mahasiswa. Oleh karena itu, pada penelitian kali ini coba dilakukan pendekatan terhadap gaya belajar (VARK) yang dimiliki sebagai dasar untuk menarik sebuah kesimpulan yang mendekati minat serta bakat calon mahasiswa dalam menentukan pilihan program studi yang sesuai. Kesimpulan yang diperoleh akan ditelusuri kembali dengan mencari sekumpulan hipotesis-hipotesis menuju fakta-fakta yang mendukung hipotesis tersebut (Backward Chaining). Berdasarkan uji komputasi yang dilakukan dengan menggunakan kedua metode tersebut diperoleh hasil bahwa pendekatan analisis dapat dilakukan dalam memberikan 
rekomendasi pilihan program studi yang sesuai dengan kemampuan calon mahasiswa.

Kata kunci: pilihan program studi, gaya belajar, rekomendasi

\section{Pendahuluan}

Menjalani pendidikan di jenjang perguruan tinggi tentu memiliki banyak tantangan, khususnya membangun komitmen untuk bisa menuntaskan masa studi dengan hasil dan prestasi yang maksimal. Sebagaimana yang diketahui bersama bahwa masa studi di jenjang sarjana setidaknya membutuhkan 8 semester atau 4 tahun. Masa tersebut tentunya menjadi tantangan tersendiri bagi mahasiswa untuk bisa melewati semester demi semester hingga mencapai kelulusan. Dalam proses penyelesaiannya, tidak sedikit mahasiswa yang gugur. Hal ini dapat dilatarbelakangi oleh beberapa faktor, diantaranya : kesulitan untuk mengikuti pembelajaran, jenuh dengan kondisi akademik di program studi tertentu, tidak menemukan sisi kritis dari dalam diri yang bisa dikembangkan, dan faktor lainnya. Dampak dari kondisi tersebut tentunya pada perolehan hasil akademik dan keberlanjutannya hingga selesai.

Berdasarkan hasil penelitian yang telah dilakukan sebelumnya, yaitu pengenalan minat dan bakat calon mahasiswa terhadap program studi yang berkesesuaian, diperoleh hasil bahwa rata-rata kecocokan antara hasil tes terhadap minat dan bakat terhadap pilihan program studi yang telah ditentukan di awal (proses registrasi) calon mahasiswa baru sangat jauh berbeda dengan rekomendasi yang disimpulkan sebagai hasil tes. (Safitri Jaya, dkk., 2017). Hasil penelitian terdahulu ini memberikan kesempatan baru untuk bisa dikembangkan lebih baik, khususnya menambahkan satu parameter baru yaitu penelusuran pada model gaya belajar.

Ada empat model gaya belajar yang dapat meningkatkan keaktifan mahasiswa yaitu Visual-Aural/Auditory, Read/Write dan Kinesthetic, atau biasa disingkat dengan istilah VARK. Metode Visual adalah sebuah metode belajar yang menyajikan materi dalam bentuk simbol seperti grafik atau diagram untuk dapat dipahami. Metode Aural adalah sebuah metode belajar yang menyajikan materi secara oral/langsung sehingga dapat langsung didengarkan dan dibahas. Metode Read/Write adalah sebuah metode belajar dengan menampilkan informasi dalam bentuk kata-kata yang bisa langsung dibaca/ditulis. Metode kinestetik adalah sebuah metode belajar melalui praktek/eksperimen secara langsung. (Riyanti dkk., 2020).

Setiap mahasiswa tentu memiliki cara dan gaya belajarnya sendiri untuk memahami sebuah pembelajaran di kelas. Gaya belajar yang berhasil diterapkan pada satu atau 
sekelompok mahasiswa belum tentu berhasil jika diterapkan pada orang/kelompok mahasiswa yang lainnya. Setiap mahasiswa harus memahami dengan baik metode belajar seperti apa yang disukai dan dapat menjadi motivasi dalam mencapai keberhasilan di bidang akademik.

Memilih program studi yang sesuai dengan minat serta bakat yang dimiliki menjadi faktor penentu bagi seorang mahasiswa untuk bisa bertahan, berprestasi di bidang akademik serta menyelesaikan masa studi tepat waktu. Hal ini tentu didasari oleh metode belajar seperti apa yang disukai, karena sedikit banyaknya akan berdampak pada program studi yang akan dipilih. Seseorang yang memiliki metode belajar Read/Write misalnya akan kesulitan jika memilih program studi yang banyak memiliki jam praktek tinggi. Berlaku juga hal sebaliknya, seseorang yang menyukai praktek dalam belajar, akan merasa sulit apabila program studi yang dipilih memiliki jam literasi/kemampuan menulis karya ilmiah yang cukup tinggi.

\section{Metode}

Metode penelitian yang digunakan pada penelitian ini adalah metode kualitatif. Proses pengumpulan data dilakukan dengan dua cara yaitu wawancara dan observasi melalui pengembangan aplikasi yang berhasil diimplementasikan. Proses wawancara dilakukan terhadap seluruh kepala program studi dan beberapa perwakilan mahasiswa program studi yang ada di Universitas Pembangunan Jaya khususnya tingkat atas. Proses ini dilakukan untuk mendapatkan gambaran mengenai gaya belajar yang biasanya dimiliki oleh mahasiswa program studi itu sendiri. Hasil wawancara akan diolah lebih lanjut untuk memperoleh draft alat ukur berupa kombinasi pola gaya belajar yang dijadikan dasar pengukuran untuk menghasilkan sebuah rekomendasi yang berkesesuaian antara gaya belajar mahasiswa dengan pilihan terhadap program studi yang ada di Universitas Pembangunan Jaya. Ada sedikit perbedaan yang diperoleh dari hasil wawancara terkait gaya belajar ini yaitu secara umum mahasiswa yang berada di bawah Fakultas Teknologi dan Desain, gaya belajar secara visual dan kinestetik dominan dimiliki oleh mahasiswa, berbeda dengan mahasiswa yang berada di bawah Fakultas Humaniora dan Bisnis yang lebih mendominasi gaya belajar secara audio dan read/write. Seluruh aktivitas ini dirangkum sebagai bentuk studi pendahulu sekaligus menghasilkan rumusan data.

Proses observasi yang dilakukan adalah melalui pengujian secara langsung pada website. Sebelum dilakukan observasi, dilaksanakan beberapa kegiatan awal sebagai pendukung diantaranya adalah adalah tahap analisis. Pada tahap ini dilakukan proses studi pendahuluan sebagai tahap awal untuk mengetahui masalah, tujuan, dan kelayakan 
pengembangan aplikasi sistem pendukung keputusan untuk pemilihan program studi menggunakan metode VARK dan Backward Chaining. Proses pengumpulan data dilakukan melalui proses wawancara, observasi lapangan, dan kajian literatur melalui buku maupun hasil penelitian terdahulu. Dari hasil analisis diperoleh spesifikasi kebutuhan perangkat lunak khususnya proses penarikan kesimpulan melalui perhitungan skor terhadap pilihan gaya belajar VARK. Data yang digunakan sebagai dasar pengujian komputasi merupakan data sekunder yang diperoleh dari pertanyaan VARK.

\section{Hasil}

Berikut adalah penjelasan terhadap beberapa hasil yang diperoleh dari penelitian :

\section{Hasil Perancangan Sistem}

Pada tahap ini dilakukan pemodelan antar muka pengguna. Terdapat tiga tampilan antar muka yaitu tampilan untuk marketing dan calon mahasiswa baru disisi front end dan tampilan pengembang disisi back end. Halaman marketing berfungsi sebagai showroom aplikasi yang dapat menampilkan seluruh informasi calon mahasiswa baru, nilai rapor serta rekomendasi program studi. Pada halaman calon mahasiswa baru terdapat fitur registrasi apabila belum terdaftar pada sistem sebagai pengguna, fitur dashboard yang terdiri dari menu input dan menu hasil rekomendasi. Pada menu input data terdapat beberapa pertanyaan yang harus dilengkapi seperti pilihan program studi, nilai rapor dan pertanyaan seputar gaya belajar sebagai alat tes. Jawaban dari alat tes tersebut akan dihitung dan dipetakan pada program studi yang sesuai dengan karakter gaya belajar calon mahasiswa. Kesimpulan yang diperoleh dari hasil tes akan ditelusuri kembali dengan nilai rapor sebagai hipotesa yang mendukung proses pengambilan keputusan /pemberian rekomendasi terhadap pilihan program studi yang sesuai. Proses uji komputasi dilakukan pada halaman pengembang yang berfungsi sebagai admin.

\section{Hasil Pengkodean untuk Kebutuhan Komputasi}

Kode yang digunakan pada konsep sistem ini adalah gaya belajar (learning styles) yang dikemukakan oleh Neil Fleming. Dimensi sistem ini diambil dari 4 tipe preferensi gaya belajar yaitu Visual, Aural/auditory, Read/write, dan Kinesthetic. Terdapat 15 kemungkinan hasil yang bisa didapatkan oleh peserta pada tabel berikut: 
Tabel 1.

Preferensi VARK

Keterangan

Visual (V)

Aural/auditory (A)

Read/write (R)

Kinesthetic (K)

Visual-Aural/auditory (VA)

Visual-Read/write (VR)

Visual-Kinesthetic (K)

Aural/auditory-Read/write (AR)

Aural/auditory-Kinesthetic (AK)

Read/write-Kinesthetic (RK)

Visual-Aural/auditory-Read/write (VAR)

Visual-Aural/auditory-Kinesthetic (VAK)

Aural/auditory-Read/write-Kinesthetic (ARK)

Visual-Read/write-Kinesthetic (VRK)

Visual-Aural/auditory-Read/write, Kinesthetic (VARK)

Pada tabel 1 di atas dapat dilihat bahwa tipe preferensi dapat disajikan berdasarkan tingkatan yaitu (Fatimah, 2018) :

a. Uni Modal/Single Preferences yaitu mencakup individu yang hanya memiliki satu preferensi gaya belajar, seperti V, A, R atau K

b. Multi-Modal mencakup individu yang terdapat lebih dari satu peferensi gaya belajar.

Terbagi menjadi 3 kategori, yaitu berikut :

1) Bi-modal Preferences, seperti VA, VR, VK, dst

2) Tri-modal Preferences, seperti VAR, SRK, dst

3) All-Four Modes, seperti VARK

Pilihan gaya belajar dari setiap pertanyaan dapat dilihat pada tabel berikut ini :

Tabel 2.

Scoring Chart

\begin{tabular}{ccccc} 
No & A & B & C & D \\
\hline 1 & V & A & R & K \\
\hline 2 & V & A & R & K \\
\hline 3 & V & A & R & K \\
\hline 4 & V & A & R & K \\
\hline 5 & V & A & R & K \\
\hline 6 & V & A & R & K \\
\hline 7 & V & A & R & K
\end{tabular}

\begin{tabular}{ccccc} 
No & A & B & C & D \\
\hline 9 & V & A & R & K \\
\hline 10 & V & A & R & K \\
\hline 11 & V & A & R & K \\
\hline 12 & V & A & R & K \\
\hline 13 & V & A & R & K \\
\hline 14 & V & A & R & K \\
\hline 15 & V & A & R & K
\end{tabular}


$\begin{array}{llllllllll}8 & \mathrm{~V} & \mathrm{~A} & \mathrm{R} & \mathrm{K} & 16 & \mathrm{~V} & \mathrm{~A} & \mathrm{R} & \mathrm{K}\end{array}$

Tabel 2 di atas menjelaskan bahwa gaya belajar dapat ditentukan/dipilih untuk setiap pertanyaan yang diberikan. Adapun total pertanyaan berjumlah 16 buah (Fleming, 2012). Kemungkinan jawaban subjek dapat dilihat pada tabel berikut ini :

Tabel 3.

Jawaban Subjek

\begin{tabular}{|c|c|c|c|c|c|c|c|c|c|}
\hline No. & $\mathbf{A}$ & B & C & D & No. & $\mathbf{A}$ & B & C & D \\
\hline 1 & $\mathrm{~A}$ & $\mathrm{~B}$ & $\mathrm{C}$ & & 9 & & & & $\mathrm{D}$ \\
\hline 2 & & B & $\mathrm{C}$ & & 10 & & & $\mathrm{C}$ & $\mathrm{D}$ \\
\hline 3 & & $\mathrm{~B}$ & $\mathrm{C}$ & & 11 & & $\mathrm{~B}$ & & \\
\hline 4 & $\mathrm{~A}$ & & $\mathrm{C}$ & & 12 & & & & $\mathrm{D}$ \\
\hline 5 & A & B & & & 13 & & & $\mathrm{C}$ & $\mathrm{D}$ \\
\hline 6 & & & & $\mathrm{D}$ & 14 & A & & & D \\
\hline 7 & $\mathrm{~A}$ & & & $\mathrm{D}$ & 15 & & B & & \\
\hline 8 & & & $\mathrm{C}$ & & 16 & $A$ & & $\mathrm{C}$ & D \\
\hline
\end{tabular}

Tabel 3 di atas menggambarkan pilihan jawaban gaya belajar oleh pengguna. Pengguna dapat memilih lebih dari satu gaya belajar. Jawaban subjek yang dikonversi dalam bentuk scoring chart dapat dilihat pada tabel berikut ini :

Tabel 4.

Jawaban subjek yang dikonversi sesuai scoring chart

\begin{tabular}{|c|c|c|c|c|c|c|c|c|c|}
\hline No & $\mathbf{V}$ & A & $\mathbf{R}$ & $\mathbf{K}$ & No & $\mathbf{V}$ & $\mathbf{A}$ & $\mathbf{R}$ & $\mathbf{K}$ \\
\hline 1 & $\mathrm{~V}$ & A & & $\mathrm{K}$ & 9 & & & & $\mathrm{~K}$ \\
\hline 2 & $\mathrm{~V}$ & & & $\mathrm{~K}$ & 10 & $\mathrm{~V}$ & & & $\mathrm{~K}$ \\
\hline 3 & & & $\mathrm{R}$ & $\mathrm{K}$ & 11 & $\mathrm{~V}$ & & & \\
\hline 4 & $\mathrm{~V}$ & & $\mathrm{R}$ & & 12 & & & & $\mathrm{~K}$ \\
\hline 5 & & & $\mathrm{R}$ & $\mathrm{K}$ & 13 & & & $\mathrm{R}$ & $\mathrm{K}$ \\
\hline 6 & & & & $\mathrm{~K}$ & 14 & $\mathrm{~V}$ & & & $\mathrm{~K}$ \\
\hline 7 & & & $\mathrm{R}$ & $\mathrm{K}$ & 15 & & & & $\mathrm{~K}$ \\
\hline 8 & & & $\mathrm{R}$ & & 16 & $\mathrm{~V}$ & $\mathrm{~A}$ & & $\mathrm{~K}$ \\
\hline
\end{tabular}

Tabel 4 di atas menjelaskan bahwa berdasarkan scoring chart, jawaban subjek pada setiap nomor soal dapat diubah sesuai gaya belajar yang dipilih (Nurakmalina, 2020).

\section{Hasil Persiapan dan Tahap Pengujian}

Pada tahap pengujian dilakukan perhitungan skor dari setiap gaya belajar dengan cara menjumlahkan jawaban subjek untuk setiap pilihan yang sesuai gaya belajarnya. Contoh perhitungan dapat dilihat pada tabel berikut : 
Tabel 5.

Jumlah subjek

\begin{tabular}{|c|c|c|c|c|c|c|c|c|c|c|c|}
\hline No & V & A & $\mathbf{R}$ & $\mathbf{K}$ & Total & No & $\mathbf{V}$ & A & $\mathbf{R}$ & $\mathbf{K}$ & Total \\
\hline 1 & $\mathrm{~V}$ & $\mathrm{~A}$ & & $\mathrm{~K}$ & & 9 & & & & $\mathrm{~K}$ & \\
\hline 2 & V & & & $\mathrm{K}$ & & 10 & $\mathrm{~V}$ & & & $\mathrm{~K}$ & \\
\hline 3 & & & $\mathrm{R}$ & $\mathrm{K}$ & & 11 & $\mathrm{~V}$ & & & & \\
\hline 4 & $\mathrm{~V}$ & & $\mathrm{R}$ & & & 12 & & & & $\mathrm{~K}$ & \\
\hline 5 & & & $\mathrm{R}$ & $\mathrm{K}$ & & 13 & & & $\mathrm{R}$ & $\mathrm{K}$ & \\
\hline 6 & & & & $\mathrm{~K}$ & & 14 & $\mathrm{~V}$ & & & $\mathrm{~K}$ & \\
\hline 7 & & & $\mathrm{R}$ & $\mathrm{K}$ & & 15 & & & & $\mathrm{~K}$ & \\
\hline 8 & & & $\mathrm{R}$ & & & 16 & $\mathrm{~V}$ & $\mathrm{~A}$ & & $\mathrm{~K}$ & \\
\hline Jumlah & 3 & 1 & 5 & 6 & 15 & Jumlah & 4 & 1 & 1 & 7 & 13 \\
\hline \multicolumn{12}{|c|}{$\begin{array}{c}\text { Total Skor } \\
15+13=28\end{array}$} \\
\hline
\end{tabular}

Tabel 5 di atas menjelaskan proses perhitungan skor dari setiap gaya belajar dengan cara menjumlahkan jawaban subjek untuk setiap pilihan yang sesuai gaya belajarnya. Berdasarkan hasil perhitungan skor, langkah selanjutnya adalah menentukan stepping distance yang mengacu pada tabel berikut ini :

Tabel 6.

Stepping Distance

\begin{tabular}{l|l} 
Total Skor & Stepping distance \\
\hline $14-21$ & 1 \\
\hline $22-27$ & 2 \\
\hline $28-32$ & 3 \\
\hline Diatas 32 & 4
\end{tabular}

Stepping distance yang tertera pada tabel 6 adalah angka acuan yang digunakan sebagai penentu kategori gaya belajar subjek Uni-Modal/Single Preference, Bi-Modal Preferences, Tri-Modal Preferences, serta Quad-Modal Preferences.

Berdasarkan skor masing-masing gaya belajar subjek, tentukan skor tertinggi, skor kedua tertinggi, skor ketiga tertinggi, serta skor terendah. Perhatikan skor tertinggi diantara semua skor tipe gaya belajar yang diperoleh subjek, kemudian kurangi jumlahnya dengan skor kedua tertinggi. Apabila hasilnya lebih besar dari pada nilai stepping distance, maka peserta tes termasuk kategori uni-modal/single preference. Unimodal/Single Preferences : Individu memiliki satu preferensi gaya belajar. Kemungkinan hasil yang dapat diperoleh individu uni-modal/single preference adalah: 
a) $\operatorname{Visual}(\mathrm{V})$,

b) Aural/auditory (A),

c) Read/write (R), dan

d) Kinesthetic (K).

Hasil pengujian yang diperoleh sebagai berikut :

Skor masing-masing tipe gaya belajar yang diperoleh subjek adalah $\mathrm{V}=3, \mathrm{~A}=7, \mathrm{R}=$ 4, $\mathrm{K}=4$, maka kurangi skor tertinggi yaitu 7 (tipe A) dengan skor kedua tertinggi yaitu 4 (tipe R dan K) sehingga diperoleh hasil yaitu 3. Karena total skor peserta tes adalah 18 (delapan belas), maka nilai stepping distance-nya adalah 1 (satu). Skor 3 (tiga) lebih besar dibandingkan nilai stepping distance yaitu 1 (satu), maka peserta tes merupakan tipe 'unimodal/single preference" dengan tipe gaya belajar Aural/auditory (A). Apabila hasilnya lebih kecil/sama dengan nilai stepping distance, maka proses skoring dilanjutkan ke tahap selanjutnya.

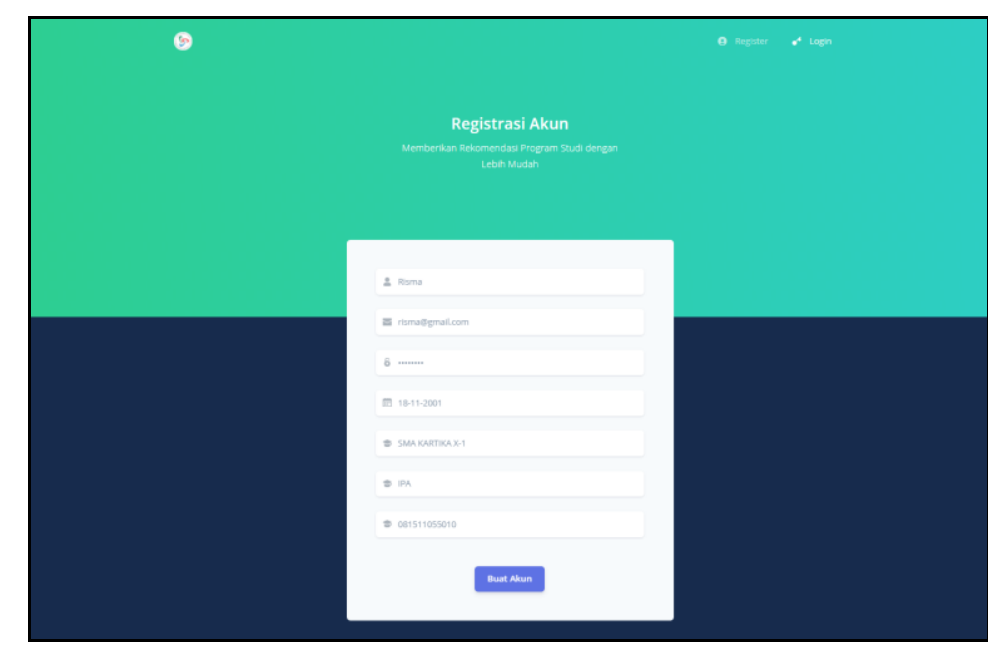

Gambar 1. Halaman registrasi calon mahasiswa baru

Halaman registrasi calon mahasiswa baru seperti yang terlihat pada gambar 1 adalah tampilan awal ketika calon mahasiswa ingin melakukan uji gaya belajar VARK. 


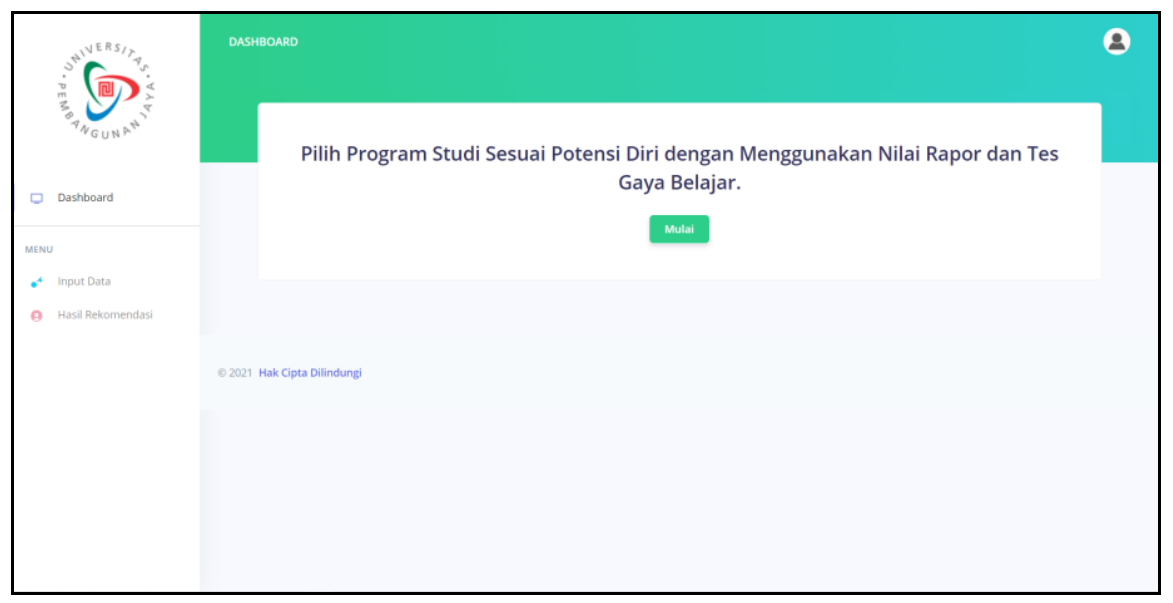

Gambar 2. Halaman Dashboard calon mahasiswa baru

Halaman dashboard seperti yang terlihat pada gambar 2 adalah tampilan setelah proses login dilakukan oleh calon mahasiswa. Terdapat 2 menu yang tersedia yaitu input data (pilihan program studi dan nilai rapor) dan hasil rekomendasi.

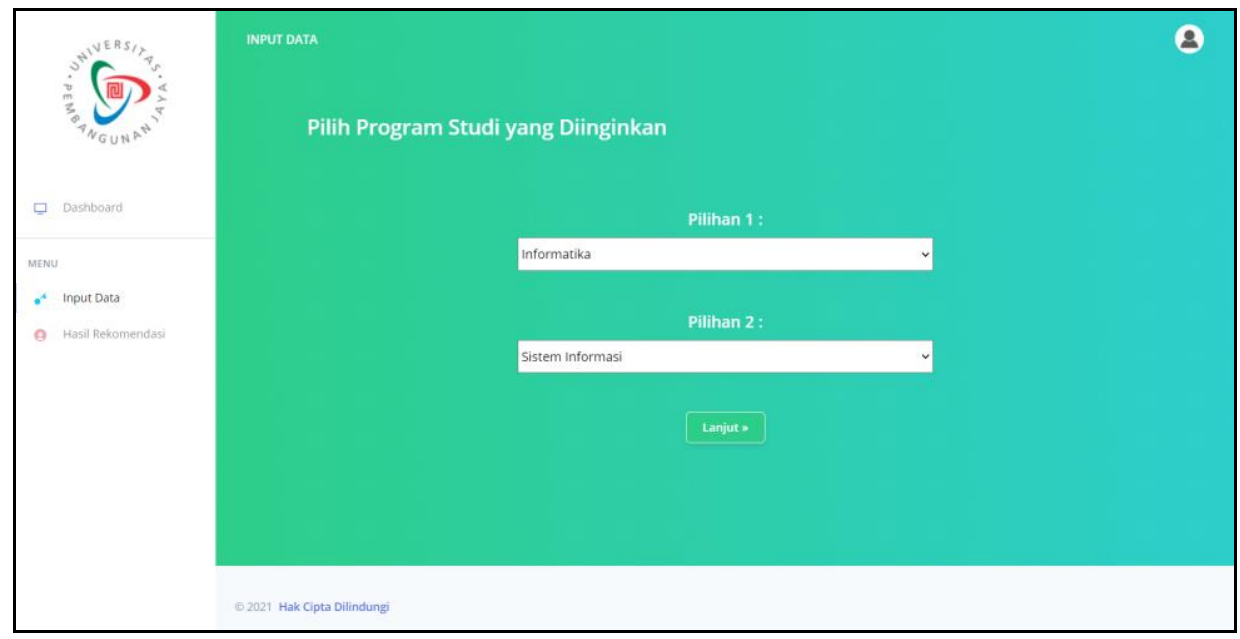

Gambar 3. Halaman input pilihan program studi

Pada menu input data (pilihan program studi) seperti yang terlihat pada gambar 3 di atas, calon mahasiswa baru dapat memilih dua program studi yang diminati. Pilihan ini akan dijadikan hipotesis untuk mendukung kesimpulan hasil skoring terhadap tes gaya belajar VARK, sebelum disimpulkan rekomendasi program studi yang sesuai dengan calon mahasiswa baru. 


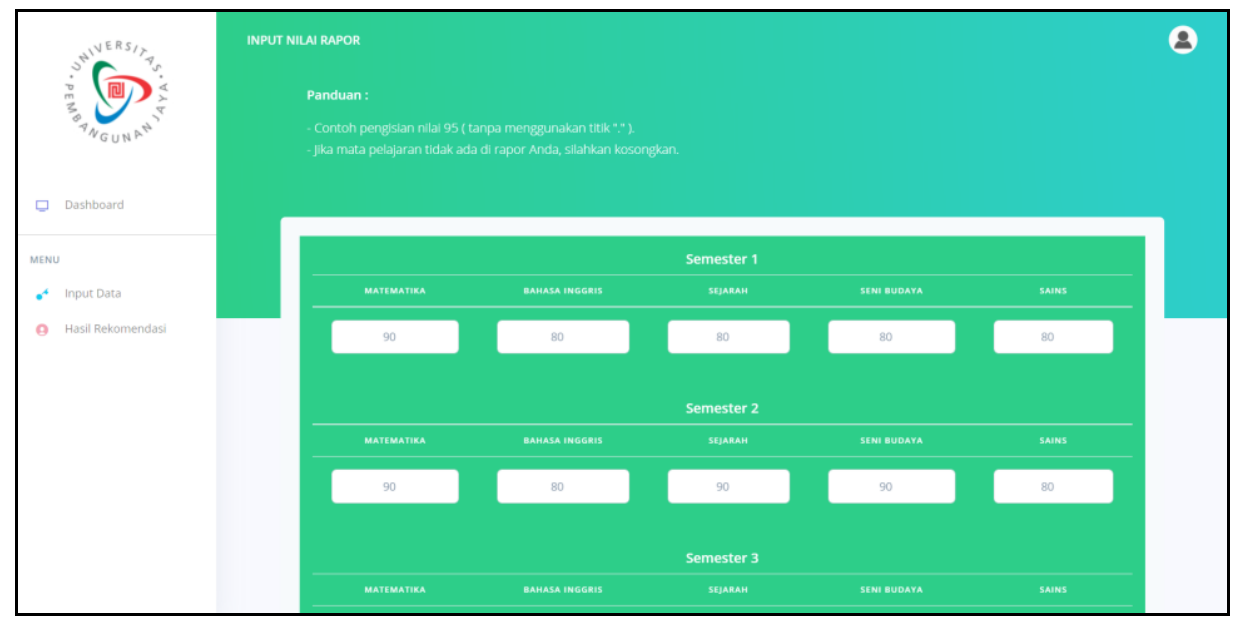

Gambar 4. Halaman input nilai rapor

Sama halnya dengan halaman input data (pilihan program studi), pada menu input data (nilai rapor) seperti yang terlihat pada gambar 4 di atas, juga digunakan sebagai hipotesis untuk mendukung kesimpulan hasil skoring terhadap tes gaya belajar VARK, sebelum disimpulkan rekomendasi program studi yang sesuai dengan calon mahasiswa baru.



Gambar 5. Halaman tes gaya belajar VARK

Pada halaman tes gaya belajar Vark seperti yang terlihat pada gambar 5 di atas, akan ditampilkan pertanyaan-pertanyaan yang mewakili masing-masing metode yang dapat dipilih oleh pengguna sesuai dengan pengalaman belajarnya. Jawaban akan disimpan dan dihitung sebagai dasar untuk penarikan kesimpulan. 


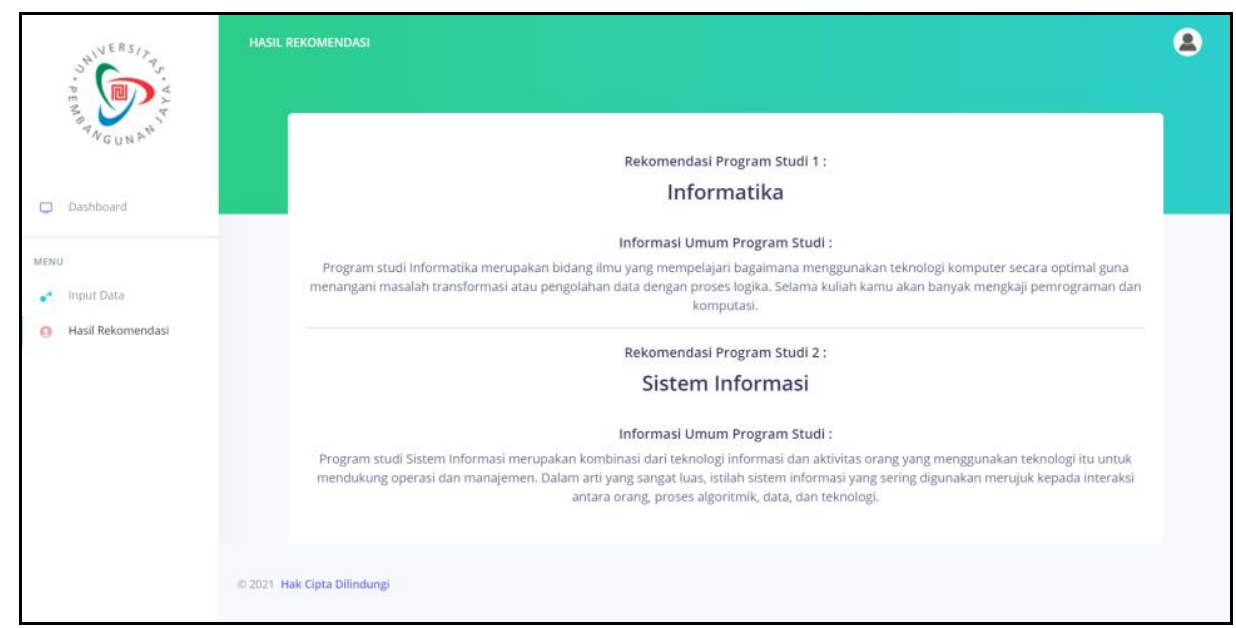

Gambar 6. Halaman hasil rekomendasi program studi

Pada menu hasil rekomendasi seperti yang terlihat pada gambar 6 di atas, adalah halaman hasil yang diperoleh dari pengujian terhadap model VARK dengan penelusuran secara backward chaining terhadap pilihan program studi dan nilai rapor yang sebelumnya sudah ditentukan diawal ketika mengisi menu input data.

\section{Diskusi}

Pentingnya pemahaman program studi terhadap gaya belajar calon mahasiswa maupun pemahaman dari calon mahasiswa sendiri terhadap gaya belajar merupakan hal yang diperlu diperhatikan, karena akan berdampak pada keberlangsungan pembelajaran serta ketuntasan dalam masa studi. Penelitian ini memiliki keutamaan untuk memberikan kemudahan kepada semua pihak untuk dapat memahami kondisi diri khususnya gaya belajar yang sesuai dengan karakter program studi berdasarkan hasil pengujian berbasis sistem.

\section{Simpulan}

Berdasarkan hasil uji komputasi terhadap sistem pendukung keputusan dalam pemilihan program studi, dapat ditarik kesimpulan sebagai diantaranya pemodelan sistem menggunakan metode VARK dapat diterapkan dan menghasilkan sebuah rekomendasi gaya belajar yang sesuai dengan pilihan program studi. Kesimpulan yang diperoleh dari hasil tes gaya belajar, dapat ditelusuri ulang dengan membandingkan antara pilihan program studi dan nilai rapor yang sudah ditentukan diawal sebelum melakukan tes gaya belajar VARK. Hasil penelusuran dapat disimpulkan sebagai rekomendasi yang sesuai dengan pilihan program studi. Hasil rekomendasi dapat ditampilkan pada aplikasi sistem 
pendukung keputusan dalam pemilihan program studi menggunakan platform berbasis web.

\section{Saran}

Penelitian selanjutnya dapat dilanjutkan dengan cara melakukan kolaborasi tes gaya belajar dengan minat mahasiswa dalam menentukan pilihan terhadap program studi. Metode pencocokan hasil tes dapat dikembangkan dengan bantuan komputasi cerdas, sehingga proses pendukung keputusan dapat diukur secara lebih kompleks.

\section{Kepustakaan}

Anastasi, A \& Urbina. (2007). Tes Psikologi: Terjemahan. Jakarta: PT Indeks

Ramdhani (2012). Adaptasi Bahasa dan Budaya dari Skala Kepribadian Big Five. Jurnal Psikologi, Vol.39. No. 2

Fleming, N. (2012). Facts, Fallacies and Myths VARK and Learning Preferences Designer of the VARK questionnaire. (Online).(www.vark-learn.com, Maret 2019).

Pressman, R.S.(2015). Rekayasa Perangkat Lunak : Pendekatan Praktisi Buku 1. Yogyakarta : Andi

Jaya,S., Anwar,C., Hermawan,H. (2017). Sistem Pemilihan Program Studi Berdasarkan Bakat, Minat Dan Kecerdasan Calon Mahasiswa Berbasis Online. SEMNASTEK UMJ 2017. Jakarta

Fatimah, A. D. (2018). a Descriptive Study of Fleming 'S Theory Based on Vark (Visual, Aural, Read/Write, Kinesthetic ) of Learning Style in Learning English Used By the Eleventh Grade Students of Man Salatiga in the Academic Year of 2017 / 2018

Riyanti, A., \& Sungkono. (2020). Pemilihan Gaya Belajar untuk Meningkatkan Keaktifan Siswa dalam Pembelajaran Bahasa Indonesia. Bahtera Indonesia; Jurnal Penelitian Bahasa Dan Sastra Indonesia , 5(1), 27-36

Nurakmalina, Arhami, M., \& Salahuddin. (2020). Desain Dan Implementasi Sistem ELearning Dengan Pendekatan Gaya Belajar Visual, Audio, Read And Kinesthetic (Vark) Studi Kasus Teknik Informatika Politeknik Negeri Lhokseumawe. Jurnal Teknologi Rekayasa Informasi Dan Komputer, 3(2), 42-47. 